\title{
BUDIDAYA ANGGUR LAUT (Caulerpa racemosa) MELALUI MEDIA TANAM RIGID QUADRANT NETS BERBAHAN BAMBU
}

\author{
Gede Ari Yudasmara \\ Jurusan Budidaya Kelautan, \\ Universitas Pendidikan Ganesha, Singaraja-Bali \\ e-mail: ariyudasmara@gmail.com
}

\begin{abstract}
Abstrak
Anggur laut (Caulerpa racemosa) merupakan makro alga hijau yang sering dimanfaatkan sebagai makanan bagi masyarakat sekitar pantai. Akan tetapi ketersediaannya masih dalam jumlah yang sangat terbatas dan musiman, karena masih tergantung dari alam dan belum dibudidayakan secara baik dan benar. Untuk itu diperlukan usaha budidaya untuk menunjang kontinuitas produksinya. Penelitian ini bertujuan untuk mengkaji dan menganalisis efektifitas dan efisiensi rigid quadrant nets berbahan bambu dalam budidaya Caulerpa racemosa dan mengkaji kualitas dan kuantitas yang diperoleh dari penerapan rigid quadrant nets berbahan bambu dalam budidaya Caulerpa racemosa. Untuk mencapai tujuan tersebut dilakukan melalui penelitian eksperimen dengan rancangan pre test post test control group design. Hasil penelitian menunjukkan bahwa rigid quadrant nets berbahan bambu cukup efektif dan efisien dalam budidaya Caulerpa racemosa, begitupula dari segi kualitas dan kuantitas substrat rigid quadrant nets berbahan bambu cukup baik kualitasnya serta hasil panen sebanyak Bak I sebesar 2340,46 gram, Bak II sebesar 2003,60 gram dan Bak ke III sebesar 2135,5 gram dengan masa penanaman selama 42 hari.
\end{abstract}

Kata kunci : budidaya, Caulerpa racemosa, media bambu

\begin{abstract}
Sea grape (Caulerpa racemosa) is a macro green algae are often used as food for people around the coast. But supply is still in very limited quantities and seasonal, because it still depends on the nature and has not been properly cultivated. It required the cultivation to support continuity of production. This study aims to examine and analyze the effectiveness and efficiency of rigid quadrant nets made from bamboo in cultivation of Caulerpa racemosa and assess the quality and quantity obtained from the application of rigid quadrant nets made of bamboo in the cultivation of Caulerpa racemosa. To achieve these goals through research experiments conducted by pre-test post-test control group design. The results showed that the rigid quadrant nets made of bamboo is quite effective and efficient in the cultivation of Caulerpa racemosa, nor in terms of quality and quantity of the quadrant rigid good enough quality and yield as much as pond I was 2340,46 grams, pond II of 2003,60 grams and pond III was 2135,5 grams with the planting period for 42 days.
\end{abstract}

Keywords: aquaculture, Caulerpa racemosa, bamboo media 


\section{PENDAHULUAN}

Sektor perikanan merupakan salah satu sumber daya alam yang sangat potensial dikembangkan dalam menunjang keberhasilan di bidang perekonomian masyarakat Indonesia. Pengelolaan sumber daya alam dan lingkungan hidup terus dilakukan untuk keseimbangan alam guna tercapainya lingkungan yang serasi. Salah satu yang potensial dikembangkan selain komoditas ikan adalah komoditas rumput laut dari jenis Caulerpa yang merupakan salah satu jenis alga hijau yang hidup menyebar di beberapa perairan di Indonesia. Dalam dunia perdagangan, rumput laut merupakan salah satu komoditas yang cukup terkenal, meskipun tidak semua jenis rumput memiliki nilai ekonomis. Rumput merupakan jenis tumbuhan laut yang tergolong makro alga yang hidup melekat di dasar perairan. Rumput laut ini belum dapat dibedakan antara batang, daun dan akarnya. Seluruh bagian tumbuhan tersebut disebut tallus.

Caulerpa merupakan salah satu genus alga laut dari Famili Caulerpaceae dan termasuk spesies dari Kelas Chlorophyceae (alga hijau) (Atmadja et al. 1996). Hamel (1931) diacu dalam Raniello et al. (2004) menyatakan bahwa jenis Caulerpa racemosa pertama kali ditemukan pada tahun 1926 di sepanjang pantai Tunisia perairan Mediterania. Makroalga laut jenis Caulerpa racemosa memiliki thalus berwarna hijau seperti tanaman rumput, terdiri dari banyak cabang tegak yang tingginya sekitar 2,5-6,0 cm. Batang pokok berukuran antara $16-22 \mathrm{~cm}$. Terdapat bulatan-bulatan seperti anggur pada puncak cabang, panjang setiap puncak cabang sekitar 2,5-10,0 cm
(Trono dan Ganzo-Fortes 1988 diacu dalam Suhartini 2003).

Caulerpa merupakan salah satu jenis rumput laut yang cukup potensial untuk dibudidayakan karena telah dikenal dan digemari oleh sebagian masyarakat. Caulerpa ini dimanfaatkan tidak hanya untuk konsumsi sebagai makanan tetapi juga telah dimanfaatkan sebagai bahan campuran untuk obat anti jamur (Suhartini, 2003). Di Indonesia Caulerpa dikenal dengan sebutan Latoh (jawa), Bulung Boni (Bali), Lawi-Lawi (Sulawesi), sedangkan di Jepang disebut Umi Budo. Caulerpa ini bentuk dan rasanya menyerupai telur ikan Caviar, sehingga dikenal sebagai "green caviar". Selain itu juga karena bentuknya menyerupai anggur, sebagian orang menyebutnya sebagai "sea grape" atau anggur laut.

Selain berwarna hijau, ciri khas Caulerpa racemosa diantaranya mempunyai thalus dengan stolon berukuran kurang lebih $5 \mathrm{~cm}$, perakarannya (holdfast) relatif besar dan meruncing seperti paku dengan panjang ramuli mencapai $8 \mathrm{~cm}$. Ramuli merupakan organ cabang atau percabangan dari stolon sebagai organ utama, substansinya agak lunak dan terkesan kosong (gembos). Ramuli ini berdiameter antara 2-4 mm. Ramuli timbul pada stolon yang bercabang dan memiliki bulatan-bulatan dengan ujung yang rata dan bertangkai serta tersusun di sekitar dan sepanjang ramuli. Pada masa reproduksi, Caulerpa racemosa akan mengeluarkan substansi berwarna putih seperti susu, namun kemudian akan mati dalam satu atau dua hari. Awalnya Caulerpa racemosa akan kehilangan warnanya, kemudian hancur dan mengotori perairan. Spesies ini 
sering ditemukan tumbuh pada berbagai substrat dengan sebaran yang luas (Atmadja et al. 1996).

Distribusi dari rumput laut jenis Caulerpa racemosa ini tersebar luas di daerah tropis dan subtropis, seperti Filipina, Vietnam, Singapura, Malaysia,Thailand, Taiwan, Cina, Indonesia, dan daerah barat perairan Pasifik (FAO 2007). Alga jenis ini tumbuh pada perairan keruh dan permukaan substrat berlumpur lunak, tepi karang yang terbuka dan terkena ombak laut yang keras serta perairan tenang yang jernih dan bersubstrat pasir keras. Jenis ini sangat kuat melekat pada substrat karena akarnya kokoh dan bercabang pendek. Alga jenis ini pada beberapa daerah seperti Tapanuli dan Kepulauan Seribu dikonsumsi baik mentah maupun matang walaupun memiliki tekstur yang kasar dengan rasa pedas seperti lada (Trono dan GanzoFortes 1988 diacu dalam Suhartini 2003).

Caulerpa racemosa tumbuh bergerombol atau berumpun oleh karena itu sering disebut sebagai anggur laut. Keberadaannya dapat dijumpai di paparan terumbu karang dengan kedalaman hingga $200 \mathrm{~m}$. Sebagai fitobentik, tumbuhan ini hidup menancap atau menempel di substrat dasar perairan laut seperti karang mati, fragmen karang, pasir dan lumpur. Pertumbuhannya bersifat epifitik atau saprofitik dan kadang-kadang berasosiasi dengan tumbuhan laut (Atmadja et al. 1996).

Caulerpa sampai saat ini pemanfaatannya masih banyak mengandalkan dari alam, hanya sedikit yang tersedia melalui budidaya karena belum ditemukannya metode atau teknik budidaya yang optimal untuk Caulerpa. Di Indonesia teknik budidaya Caulerpa ini dilakukan dengan cara membenamkannya ke dalam substrat tanah seperti sistem menanam padi pada areal/lahan bekas tambak atau mengadopsi teknik budidaya seperti halnya di Jepang. Kondisi inilah yang menimbulkan permasalahan karena tidak disemua wilayah pesisir memiliki areal bekas tambak dan mahalnya biaya operasional teknologi budidaya dari Jepang tersebut.

Oleh karena itu diperlukan suatu alih teknologi tepat guna untuk mengatasi permasalahan tersebut. Salah satunya dapat digunakan melalui rigid quadrant nets berbahan bambu untuk media tanamnya. Teknik ini diharapkan mampu mengatasi kendalakendala dalam pembudayaan Caulerpa racemosa untuk menunjang keberadaannya dalam jumlah besar dan secara kontinu, mengingat teknik ini mudah diterapkan, murah dari segi biaya pembuatan dan ramah lingkungan karena memanfaatkan bahan baku berupa bambu sehingga sangat mudah untuk diaplikasikan oleh masyarakat.

Dalam penelitian ini yang menjadi tujuan utamanya adalah untuk mengkaji dan menganalisis efektifitas dan efisiensi rigid quadrant nets berbahan bambu dalam budidaya Caulerpa racemosa dan mengkaji kualitas dan kuantitas yang diperoleh dari penerapan rigid quadrant nets berbahan bambu dalam budidaya Caulerpa racemosa dalam mewujudkan pembudidayaan yang optimal dan ramah lingkungan guna meningkatkan daya saing masyarakat Buleleng. 


\section{METODE PENELITIAN}

Penelitian ini menggunakan jenis penelitian eksperimental dengan rancangan pre test post test control group design. Penelitian ini dilakukan dengan 3 kali ulangan. Bibit Caulerpa racemosa ditempatkan dalam anyaman bambu berukuran $50 \times 50 \mathrm{~cm}$ berada di atas permukaan air dengan ketinggian air dari dasar bak adalah $60 \mathrm{~cm}$. Air yang digunakan adalah air yang bersirkulasi serta diberikan pupuk NPK secara berkala. Bak yang digunakan adalah bak beton dengan ukuran $3 \times 2$ meter dengan ketinggian $1,5 \mathrm{~m}$. Aerasi diberikan pada masing-masing bak sebagai suplai oksigen. Setiap bak diberikan dua selang aerasi lengkap dengan batu aerasinya. Kemudian semua selang dalam masing-masing bak penelitian dihubungkan dengan aerator.
Pengumpulan data dilakukan dengan mencatat berat bibit awal yang ditanam dan mencatat hasil panen yang diperoleh melalui penimbangan berat anggur laut. Bibit awal Caulerpa racemosa sebesar 1000 gram yang akan diamati selama 42 hari.

\section{HASIL dan PEMBAHASAN HASIL}

Hasil pengamatan menunjukkan bahwa budidaya Caulerpa racemosa dengan menggunakan rigid quadrant nets berbahan bambu memberikan hasil panen sebanyak bak I sebesar 2340,46 gram, bak II sebesar 2003,60 gram dan bak ke III sebesar 2135,5 gram dengan masa penanaman selama 42 hari. Selisih berat yang diperoleh dari ketiga ulangan yang dilakukan telah melebihi berat awal yang ditebar di dalam anyaman bambu. Perbandingan berat dari awal sampai panen dapat dilihat pada Tabel 3.1 berikut ini.

Tabel 1. Perbandingan Berat awal dan Berat Akhir Caulerpa racemosa

\begin{tabular}{|c|c|c|c|}
\hline Bak & $\begin{array}{c}\text { Berat Awal } \\
\text { (gram) }\end{array}$ & $\begin{array}{c}\text { Berat Akhir } \\
\text { (gram) }\end{array}$ & $\begin{array}{c}\text { Selisih Berat } \\
\text { (gram) }\end{array}$ \\
\hline I & 1000 & 2340,46 & 1340,46 \\
\hline II & 1000 & 2003,60 & 1003,60 \\
\hline III & 1000 & 2135,5 & 1135,5 \\
\hline
\end{tabular}

Hasil pengukuran parameter fisika kimia tentang komponen air yang mempengaruhi laju pertumbuhan
Anggur Laut. Data tersebut dapat dilihat pada Tabel 2 berikut ini. 
Tabel 2 Hasil Pengukuran Fisika Kimia Air Pada Tiga Bak

\begin{tabular}{|c|c|c|c|c|}
\hline Bak & Suhu $\left({ }^{0} \mathrm{C}\right)$ & $\mathrm{pH}$ & Salinitas $(\mathrm{ppt})$ & $\mathrm{DO}(\mathrm{mg} / \mathrm{l})$ \\
\hline I & 28 & 7.9 & 30 & 5.6 \\
\hline II & 29 & 7.7 & 31 & 5.5 \\
\hline III & 29 & 7.7 & 31 & 5.5 \\
\hline Rerata & 28.6 & 7.8 & 30.6 & 5.53 \\
\hline
\end{tabular}

Berdasarkan data pada Tabel 3.1 dapat dibuat grafik perbandingan berat awal Anggur Laut dengan berat akhir hasil

panen Anggur Laut. Grafik perbandingan dapat dilihat pada Gambar 1.

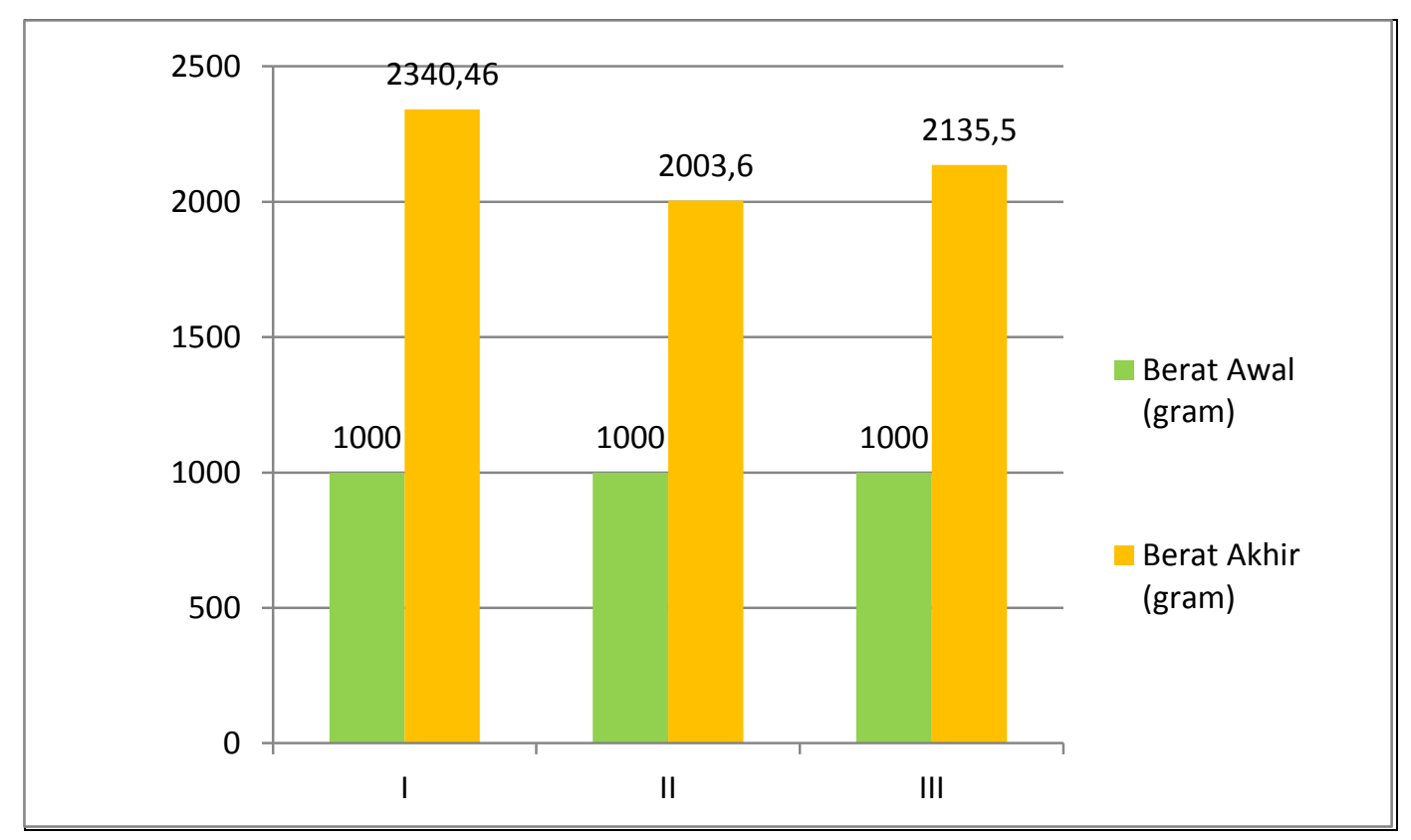

Gambar 1 Perbandingan Berat Anggur Laut 


\section{PEMBAHASAN \\ Kuantitas dan Kualitas Caulerpa racemosa}

Gambar 1. menunjukkan bahwa penerapan rigid quadrant nets berbahan bambu atau dengan kata lain menggunakan substrat penempelan berbahan bambu secara kuantitas (jumlah hasil panen) tergolong baik, karena dari ketiga ulangan yang dilakukan bobot hasil panen melebihi 2 kali bobot awal penanaman.

Menurut CBAD (2012) Caulerpa sp bisa tumbuh antara 10 - 13 kali setelah 3 bulan masa pemeliharaan, dimana berat awal 500 gr menjadi 6000 gr serta dengan bibit awal 120 - $140 \mathrm{~kg}$, bisa dipanen setelah 20 hari, mencapai 900 $\mathrm{kg} \mathrm{-} 1400 \mathrm{~kg}$ dan berikutnya bisa dipanen tiap hari $(40 \mathrm{~kg}-80 \mathrm{~kg})$ selama 15 hari.

Substrat atau media tanam berfungsi sebagai tempat melekatnya anggur laut, sedangkan anggur laut mendapatkan makanan dari air di sekitarnya melalui proses difusi. Media bambu tergolong baik dapat disebabkan karena permukaannya yang agak kasar

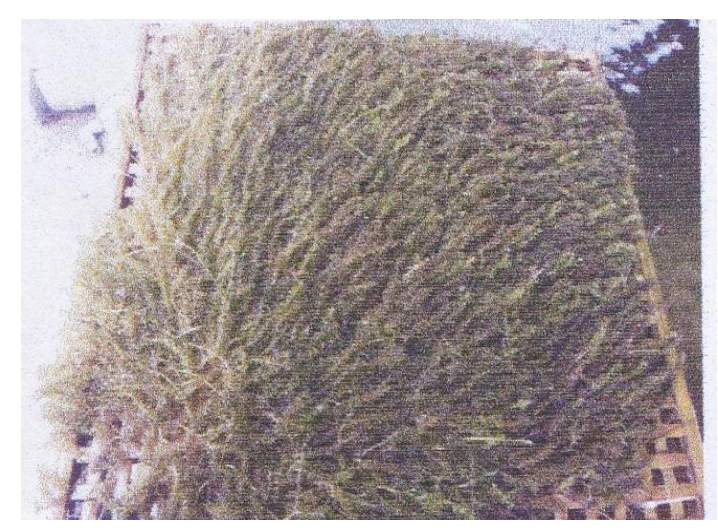

Gambar 2.Bibit Anggur Laut dan kaku sehingga rizoid lebih mudah untuk menempel dan berkembang. Di alam Caulerpa racemosa melekat pada batu atau substrat yang agak kasar untuk hidupnya.

Menurut Trono dan Ganzo-Fortes (1988) diacu dalam Suhartini (2003) anggur laut tumbuh pada perairan keruh dan permukaan substrat berlumpur lunak, tepi karang yang terbuka dan terkena ombak laut yang keras serta perairan tenang yang jernih dan bersubstrat pasir keras. Jenis ini sangat kuat melekat pada substrat karena akarnya kokoh dan bercabang pendek.

Jenis substrat memegang peranan dalam kehidupan alga, oleh karena itu substrat harus diperhatikan derajat kekerasannya, kelembutannya, ketidak teraturannya dan lain sebagainya. Tipe substrat ada bermacam-macam, yaitu pasir, lumpur, pasir campur lumpur, karang mati, karang hidup, dan pecahan karang. Akan tetapi menurut Mubarak (1982) tipe substrat yang ideal untuk pertumbuhan alga adalah reef area dengan dasar pasir karang bercampur dengan potongan karang.

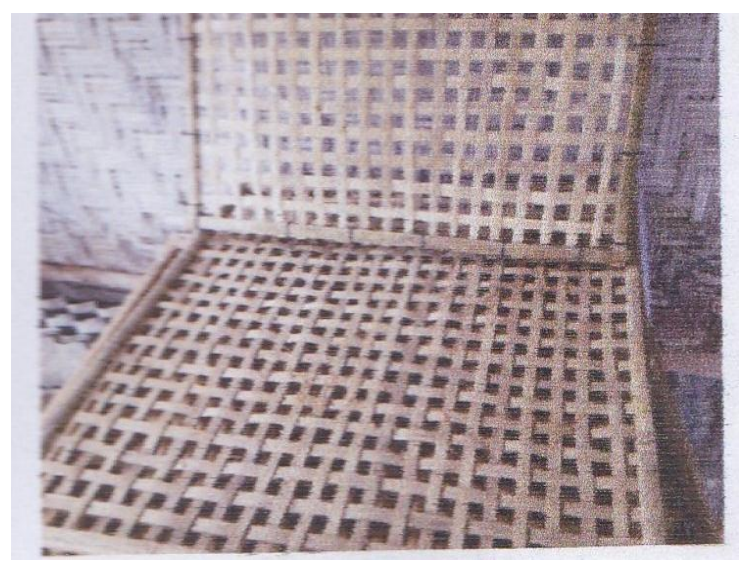

Gambar 3 Media Tanam 

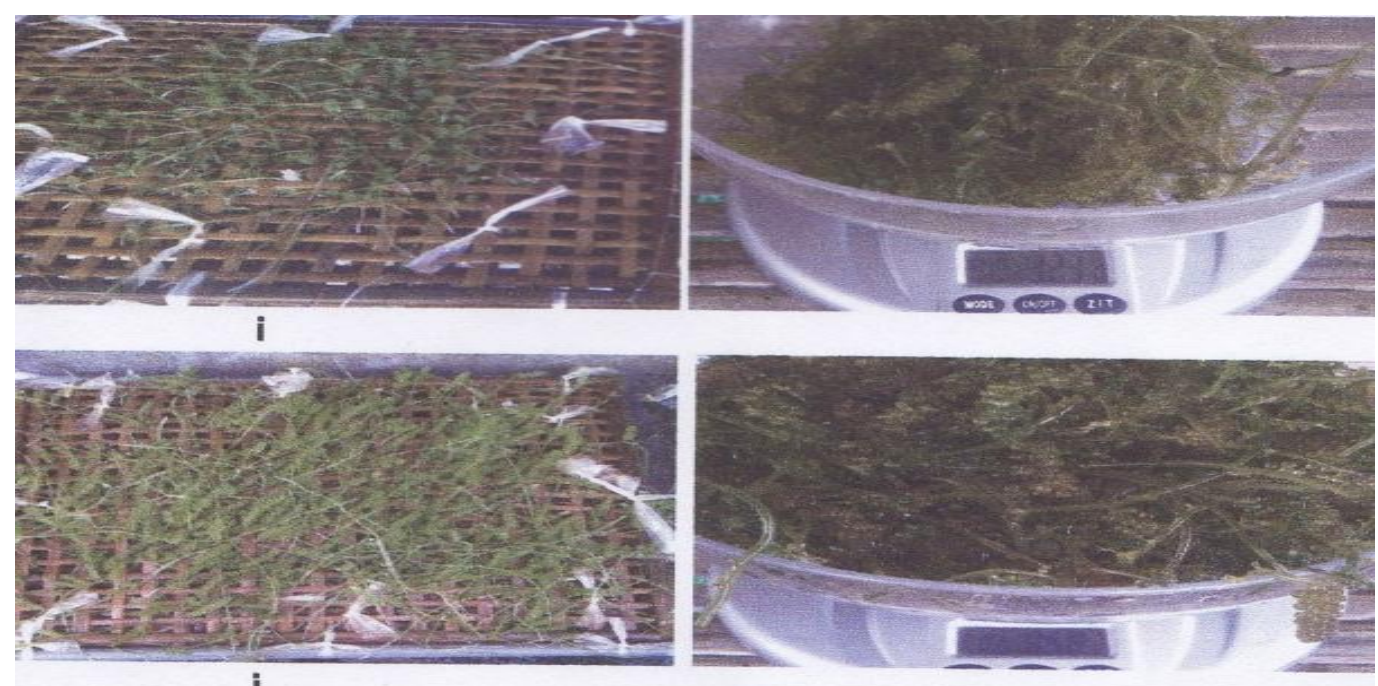

j
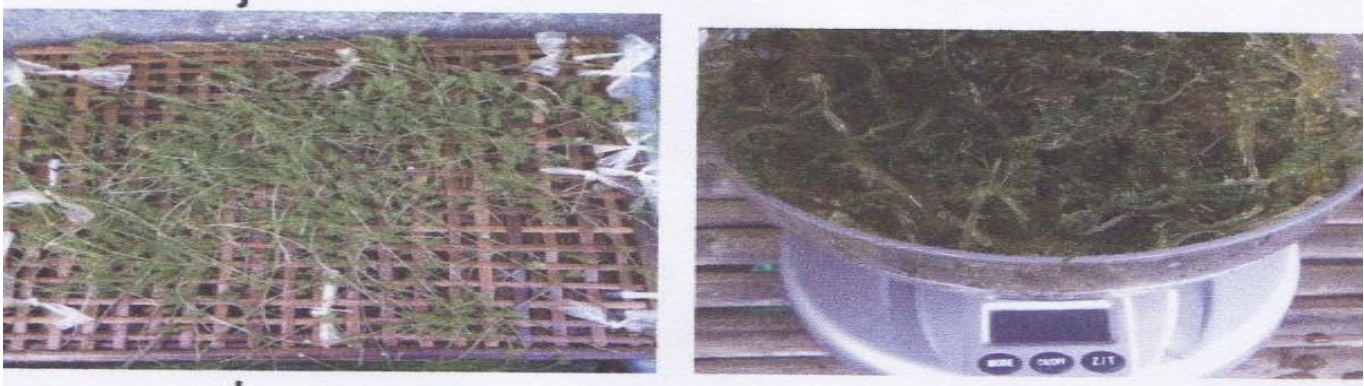

k
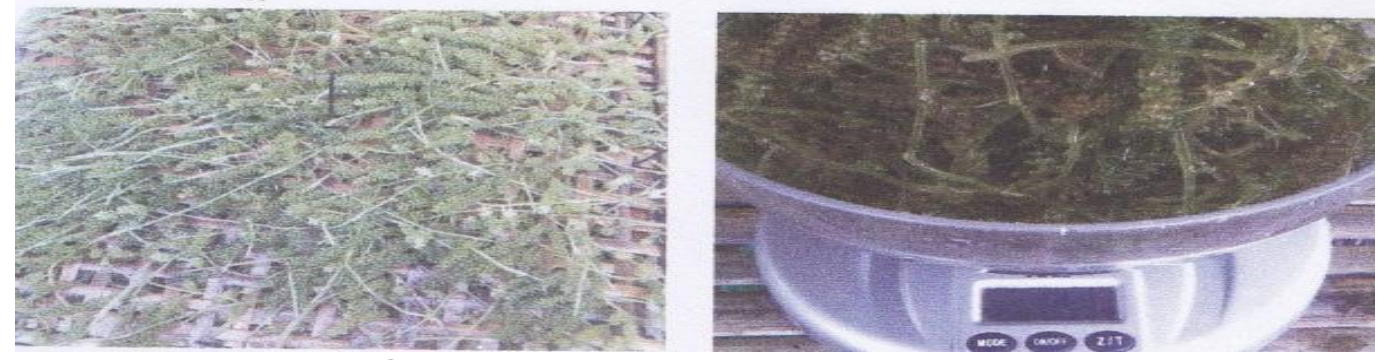

Gambar 4. Pertumbuhan Anggur Laut

Dari segi kualitas, Anggur laut yang dihasilkan menunjukkan kualitas yang tergolong baik, yaitu hijau tidak ada bercak putih dan tidak mudah rapuh sehingga layak untuk dijual atau dikonsumsi.
Thallus yang memutih, berlendir, mudah putus dan akhirnya mati, hal ini merupakan tanda adanya penyakit "ice ice". Sesuai dengan pernyataan Doty (1987) dalam Yulianto dan Mira (2009), bahwa gejala "ice-ice" yaitu kondisi 
thallus terdapat bercak berwarna putih, berlendir dan semakin lama thallus patah. Ditambahkan oleh Trono (1988) yang menyatakan penyakit ini terjadi karena perubahan kondisi lingkungan yang tidak sesuai untuk pertumbuhan yang menyebabkan menurunnya daya tahan tanaman tersebut.

Selain itu, pertumbuhan yang cukup bagus ini dapat disebabkan karena Anggur lautnya diberikan pupuk NPK secara berkala sehingga pertumbuhannya menjadi optimal. Hal ini sesuai dengan Balingar dan Duncan (1990) dalam Anggorowati (2004) yang menyatakan apabila tanaman tidak mendapat hara yang cukup, maka pertumbuhan dan perkembangannya akan terhambat, demikian sebaliknya, apabila tanaman mendapat hara yang berlebih, maka pertumbuhan dan perkembangannya juga akan terhambat.

Menurut Hutabarat (2000), kandungan $\mathrm{P}$ di perairan tergolong tinggi jika nilainya diatas $0.1 \mathrm{ppm}$ dan menurut Pratiwi (1996), kondisi optimum kandungan $\mathrm{NO}^{3}-\mathrm{N}$ untuk pertumbuhan alga di perairan tambak adalah sebesar 0,9 - 3,5 ppm. Seperti diketahui N dan P adalah unsur hara yang sangat dibutuhkan oleh alga dalam pertumbuhannya. Unsur $\mathrm{P}$ yang sedikit jumlahnya serta dalam perbandingannya dengan unsur $\mathrm{N}$ yang tidak serasi seringkali merupakan faktor pembatas bagi pertumbuhan alga (Hutabarat, 2000).

Keadaan lain yang ikut mempengaruhi laju pertumbuhan Anggur laut adalah parameter fisikakimia air, dimana komponen fisika kimia perairan seperti suhu, salinitas, $\mathrm{pH}$ dan DO masih dalam kisaran yang sesuai untuk pertumbuhan Anggur laut.
Hasil pengukuran kualitas air menunjukkan bahwa rata-rata suhu di bak percobaan berkisar antara $28,6{ }^{\circ} \mathrm{C}$, kondisi suhu tersebut cukup mendukung kelangsungan hidup organisme di air. Menurut Romimohtarto dan Juwana (2001), temperatur yang baik untuk mendukung kelangsungan hidup organisme di laut berkisar antara 28 - 30 ${ }^{\circ} \mathrm{C}$. Sedangkan menurut Soegiarto dkk. (1978) temperatur yang baik untuk kehidupan rumput laut adalah sekitar $27,5^{\circ} \mathrm{C}$.

Suhu merupakan faktor lingkungan yang sangat berpengaruh terhadap pertumbuhan dan perkembangan Anggur Laut karena akan berpengaruh langsung terhadap proses metabolismenya. Suhu yang terlalu tinggi akan menyebabkan Anggur Laut memperlambat proses pertumbuhannya akibat menurunnya kerja enzim (degradasi enzim) dan cepat mengalami pemutihan thalus dan lepasnya ramuli (Hanafi, 2007).

Didalam penelitian ini rata-rata suhu yang diperoleh sesuai dengan kisaran optimal suhu untuk pertumbuhan Anggur Laut dapat disebabkan karena dalam penelitian ini juga menggunakan waring sebagai penutup bagian atas bak (shading), sehingga dengan demikian paparan sinar matahari tidak terlalu kuat untuk masuk mengenai Anggur Laut itu sendiri dan hal ini sudah tentu mempengaruhi kondisi suhu untuk tetap stabil, selain itu penggunaan waring juga bermanfaat dimalam hari, karena suhu didalam bak tidak menjadi turun drastis akibat masih terperangkapnya suhu di dalam bak (thermal block).

Air laut di perairan tempat penelitian dilakukan mempunyai rata-rata $\mathrm{pH}$ antara 7.8. Kondisi $\mathrm{pH}$ tersebut sesuai 
untuk pertumbuhan alga, hal ini sesuai dengan pendapat Odum (1971) yang mengatakan bahwa $\mathrm{pH}$ yang baik untuk pertumbuhan alga adalah 5 - 8 .

Salinitas yang terukur selama penelitian di bak, rata-rata berkisar 30.6 ppt. Salinitas tersebut cukup wajar untuk mendukung kehidupan alga. Menurut Perry (2003), alga sublitoral dapat mentolerir salinitas 0,5 - 1,5 kali dari salinitas normal (16 - 50 ppt). Sedangkan Alga intertidal mampu hidup pada kisaran salinitas $0,1 \quad$ - 3,5 kali salinitas normal. Selanjutnya Dawes (1987) mengatakan bahwa makroalga masih dapat hidup pada salinitas antara 5 - 35 ppt.

Selain itu, parameter fisika kimia perairan yang paling berpengaruh adalah intensitas sinar matahari yang masuk ke dalam bak percobaan. Hal ini dikarenakan Anggur laut merupakan tumbuhan berklorofil yang memerlukan sinar matahari untuk pertumbuhannya, sehingga untuk pertumbuhannya rumput laut hanya terbatas pada tempat yang dangkal saja (Smith, 1951 dalam Azizah dkk. 1991).

Doty (1961) dalam Azizah dkk. (1991) membuat suatu monogram intensitas sinar yang masuk ke dalam air dalam prosen. Hasil pengamatan sechi disk dapat diketahui bahwa lapisan kedalaman $40 \mathrm{~cm}$ mempunyai intensitas sinar $85 \%$, kedalaman $80 \mathrm{~cm}$ mempunyai intensitas sinar $75 \%$ dan kedalaman $120 \mathrm{~cm}$ mempunyai intensitas sinar sekitar $60 \%$. Sedangkan Feldman (1951) dalam Azizah, dkk. (1991) mengatakan bahwa perbedaan penyinaran baik kualitatif maupun kuantitatif pada keadaan yang berbeda-beda akan mempengaruhi fotosintesa dari alga. Lebih lanjut
Dawson (1966) dalam Azizah dkk. (1991) menambahkan bahwa variasi intensitas sinar yang diterima thallus secara sempurna merupakan faktor utama dalam fotosintesa yang akan menunjang laju pertumbuhan alga.

\section{Efektifitas dan Efisiensi Substrat Berbahan Bambu}

Dilihat dari hasil panen menggunakan media tanam berbahan bambu, dapat dikatakan bahwa rigid quadrant nets berbahan bambu dalam budidaya Caulerpa racemosa cukup efektif, sedangkan dari segi efisiensi penggunaan bambu lebih murah dari segi harga dan mudah untuk dicari karena di alam bahan ini mudah untuk didapatkan dan tersedia dalam jumlah yang banyak sehingga bagi para pembudidaya dapat lebih hemat dalam biaya produksinya.

\section{SIMPULAN DAN SARAN Simpulan}

1. Secara kualitas dan kuantitas hasil panen menggunakan substrat berbahan bambu tergolong baik.

2. Substrat berbahan bambu cukup efektif dan efisien untuk membudidayakan Caulerpa racemosa.

\section{Saran}

1. Untuk penelitian selanjutnya, bahan yang digunakan diupayakan dari jenis Caulerpa yang lain, agar terdapat keragaman jenis Anggur Laut yang dapat dibudidayakan.

2. Perlu diuji cobakan langsung di perairan laut, untuk memfasilitasi masyarakat pesisir yang tidak memiliki bak budidaya. 


\section{DAFTAR PUSTAKA}

Atmadja PS, Kadi A, Sulistijo, Satari R. 1996. Pengenalan Jenis-Jenis Rumput Laut Indonesia. Jakarta: Puslitbang Oseanologi LIPI.

Anggadiredja, J.T., Zatnika, A., Purwoto, H., Istini, S. 2006. Rumput Laut. Jakarta: Penebar Swadaya.

Anggorowati, D.A. 2004. Bioeliminasi Nitrat oleh Gracilaria salicornia pada Kegiatan Marikultur. UPT Loka Pengembangan BioIndustri Mataram-Puslit.

Oseanografi. 297 - 303 HIm.Aslan. 1991.Budidaya Rumput Laut. Penerbit Kanisius Yogyakarta.

Azizah R. TN., Susanto, AB., dan Pramesti R., 1991. Uji Coba Budidaya Rumput Laut Jenis Eucheuma cottonii dengan Metoda Terapung di Perairan Bandengan, Jepara. Lembaga Penelitian Universitas Diponegoro, Semarang.

Budiyani, F.B., Ken, S., Sunaryo. 2012. Pengaruh Penambahan Nitrogen dengan terhadap Laju Pertumbuhan Rumput Laut Caulerpa racemosa var. uvifera. Journal of Marine Research. Volume 1, Nomor 1, Tahun 2012, Halaman 10-18. Semarang: Uiversitas Diponegoro.

Dawes, C.J. 1987. The Biology of Commercial Important Tropical Marine Algae dalam Bird. K.T. dan P.H. Benson (ed.) Seaweed Cultivation For Renewable Resources. Elsevier. Amsterdam.
Dwihandita, N. 2009. Perubahan Kandungan Antioksidan Anggur Laut (Caulerpa racemosa) Akibat Pengolahan. [Skripsi]. Bogor: Program Studi Teknologi Hasil Perikanan. Fakultas Perikanan dan IImu Kelautan. Institut Pertanian Bogor.

Hamid, A. 2009. Pengaruh berat bibit awal dengan metode apung (floating method) terhadap presentase pertumbuhan harian rumput laut (Euchema cottoni). Skripsi. Fakultas Sains dan Teknologi UIN Maulana Malik Ibrahim. Malang. $48 \mathrm{HIm}$.

Hanafi, A. 2007. Teknik Produksi Anggur Laut (Caulerpa racemosa), Prosiding Simposium Nasional Hasil riset Kelautan dan Perikanan. Jakarta: LIPI.

Hutabarat, S. 2000. Produktivitas Perairan dan Plankton Telaah terhadap Ilmu Perikanan dan Kelautan.Badan Penerbit UNDIP, Semarang.

Odum, E.P. 1971. Fundamental of Ecology. W.B. Sounders Company. Philadelphia. 574 hal.

Perry, R. 2003. A Guide to the Marine Phytoplankton of Southern California. Dipublikasikan: www. msc. Ucla/oceanglobe/pdf/guide. 23 hlm. 25 Mei 2013.

Raharjo, S. 2012. Budidaya Lawi-Lawi (Caulerpa sp) Di Tambak Sebagai Upaya Diversifikasi Budidaya Perikanan. Indonesian Aquaculture dan Forum Inovasi Teknologi Akuakultur. Makassar. 
Romimohtarto dan Juwana, 2001. Biologi Laut. P3O LIPI, Jakarta.

Soegiarto, A., Sulistijo., Atmadja W.S., Mubarak H. 1978. Rumput Laut (Algae): Manfaat, Potensi dan Usaha Budidayanya. Jakarta: Lembaga Oseanografi NasionalLIPI.

Suhartini, S. 2003. Penapisan awal Caulerpa racemosa, Sesuvium portulacastrum, Xylocarpus granatum dan Ulva lactuca Sebagai Antimikroba. [Skripsi]. Bogor: Program Studi Teknologi
Hasil Perikanan. Fakultas Perikanan dan IImu Kelautan. Institut Pertanian Bogor.

Trono, G.C. 1988. Field Culture of Gracilaria and Other Species. National Science Research Center. Philipina. 158 p.

Yulianto, K dan S. Mira. 2009. Budidaya makroalga Kappaphycus alvarezii (doty) secara vertikal dan gejala penyakit "ice-ice" di perairan Pulau Pari. Jurnal Oseanologi dan Limnologi di Indonesia. 35 (3): 325-334. 